\title{
Additional Radiocarbon Dates from East Texas Caddo Sites
}

Timothy K. Perttula

Heritage Research Center, Stephen F. Austin State University

Robert Z. Selden Jr.

Heritage Research Center, Stephen F. Austin State University

Follow this and additional works at: https://scholarworks.sfasu.edu/ita

Part of the American Material Culture Commons, Archaeological Anthropology Commons, Environmental Studies Commons, Other American Studies Commons, Other Arts and Humanities Commons, Other History of Art, Architecture, and Archaeology Commons, and the United States History Commons

Tell us how this article helped you.

This Article is brought to you for free and open access by the Center for Regional Heritage Research at SFA ScholarWorks. It has been accepted for inclusion in Index of Texas Archaeology: Open Access Gray Literature from the Lone Star State by an authorized editor of SFA ScholarWorks. For more information, please contact cdsscholarworks@sfasu.edu. 


\section{Additional Radiocarbon Dates from East Texas Caddo Sites}

Creative Commons License

(c) (i) (8)

This work is licensed under a Creative Commons Attribution-NonCommercial 4.0 International License 


\title{
Additional Radiocarbon Dates from East Texas Caddo Sites
}

\author{
Timothy K. Perttula and Robert Z. Selden Jr.
}

\section{INTRODUCTION}

This article reports on two new radiocarbon dates obtained from ancestral Caddo sites in East Texas. These dates provide new information on the ages of Caddo occupations at the sites, and they contribute to the further expansion of the East Texas Caddo radiocarbon database (Selden and Perttula 2013a, 2013b).

\section{RADIOCARBON DATE FROM THE SANDERS SITE (41LR2)}

Two samples of deer bone from the Sanders site in the collections from the Texas Archeological Research Laboratory at The University of Texas at Austin (TARL) were submitted to DirectAMS for radiocarbon dating. One deer bone, a deer leg bone, contained insufficient collagen for dating purposes, but the other sample, a deer phalange, was able to be dated. Both deer bones came from a midden deposit immediately north of Mound No. 2, the West Mound (see Krieger 1946:Figure 9) at the site.

The deer phalange has a conventional radiocarbon age of $374 \pm 24$ years B.P. (A.D. 1552-1600) (D-AMS 006436). The 2 sigma calibrated age range of this date is A.D. 1448-1631, with a median calibrated age of A.D. 1503. At 2 sigma, the age range probabilities are A.D. 1448-1524 (63 percent) and A.D. 1572-1631 (32 percent). This 16th to possible early 17th century calibrated date from the Sanders site is not inconsistent with the nature of the archaeological record now known from the study of new collections obtained from the site in the spring of 2014 as well as the recent analyses of artifact collections from TARL and the National Museum of Natural History at the Smithsonian Institution (Perttula 2015).

\section{RADIOCARBON DATE FROM THE SUSIE SLADE SITE (41HS13)}

The Susie Slade site is an ancestral Caddo settlement and cemetery on a sandy knoll in the Potters Creek valley in the Sabine River basin. Jones (1968) excavated three burials of historic age (i.e.,, post-A.D. 1685 ) at the site, and the site is known to have had a large cemetery ( $>50$ burials) that was excavated by a number of East Texas collectors and amateur archaeologists. These burials were spaced from 1.8-4 m apart, and they were oriented in extended supine position in east-west pits, with the head of the deceased facing to the west or southwest (Jones 1968:102).

In June 1962, Buddy Jones excavated the aforementioned three burials, one of which contained a La Rue Neck Banded jar (Figure 1) from Burial 2 with substantial amounts of organic residue preserved on interior and exterior surfaces (Perttula et al. 2014). Burial 2 had six ceramic vessels, 30 marine conch shell beads, gray clay pigment, and a deer mandible (Jones 1968:106). Utility wares in the collections from the Susie Slade burials include La Rue Neck Banded and Emory Punctated-Incised jars. Fine wares are comprised of Natchitoches Engraved ( $\mathrm{n}=3$ vessels in Burial 3), a post-A.D. 1685 ceramic ware, Simms Engraved, Simms Engraved, var. Darco, a Hood Engraved effigy vessel, and Ripley Engraved. 


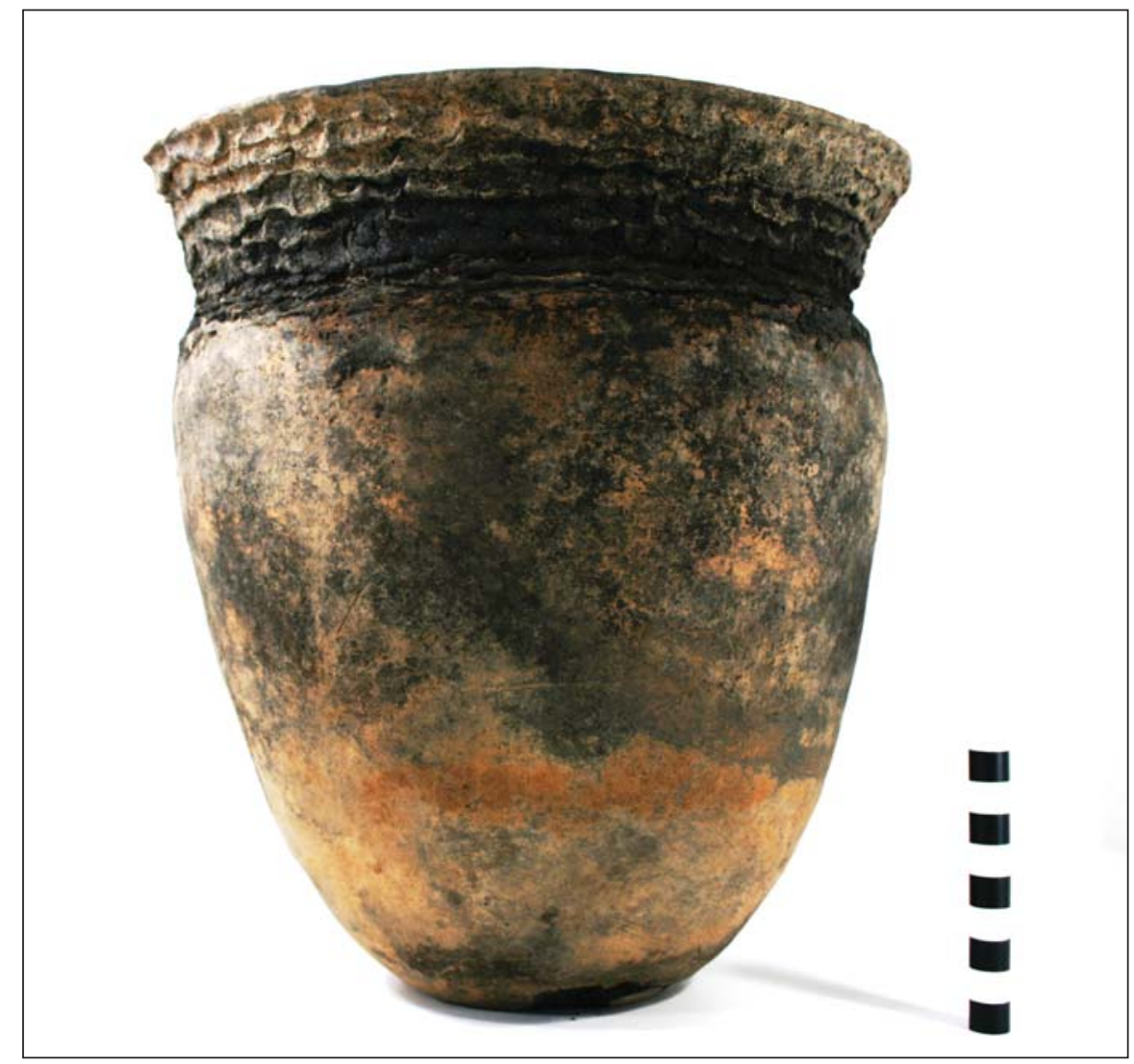

Figure 1. LaRue Neck Banded jar, Burial 2, Susie Slade site.

Organic residue from the exterior rim and body of the jar was first radiocarbon dated by Perttula and Selden (2014). That date has a two sigma calibrated age range of A.D. 1662-1811, and the highest probabilities are between A.D. 1728-1811 (D-AMS 003664). A second date was also obtained on organic residue preserved on an incised-punctated jar; the organic residue on this vessel has a 2 sigma calibrated age range of A.D. 1652-1880. The median calibrated dates from the two vessels at the Susie Slade site range between A.D. 1769-1774, indicating a late 18th century use of the vessels before they were interred in Burials 1 and 2. The likeliest probabilities of the two calibrated dates fall between A.D. 1720-1819 and A.D. 1728-1811 (Perttula and Selden 2014).

To definitively establish the age of the La Rue Neck Banded vessel, and of the Historic Caddo occupation at the Susie Slade site, a second sample of organic residue from the La Rue Neck Banded jar was submitted for radiocarbon dating. This residue sample has a conventional radiocarbon age of $171 \pm 29$ years B.P. (A.D. 1750-1808) (D-AMS 006437). The calibrated 2 sigma age range of this sample is A.D. 1661-1815, with a median calibrated age of A.D. 1771. The highest probabilities are associated with calibrated age ranges of A.D. 1725-1815 (51 percent) and A.D. 1661-1698 (17 percent).

Considering this third date from the Susie Slade site in conjunction with the two earlier dates reported by Perttula and Selden (2014), the median calibrated dates for all three samples range between A.D. 17691774, and the likeliest probabilities of the three dates overlap between A.D. 1720-1811. They clearly support the occupation of the Susie Slade site by the Nadaco Caddo during much of the Historic Caddo period. 


\section{SUMMARY}

Two new radiocarbon dates have been obtained from two Caddo sites in East Texas: the Sanders site (41LR2) on the upper Red River and the Susie Slade site (41HS13) in the mid-Sabine River basin. The calibrated radiocarbon date from the Sanders site has a 2 sigma age range of A.D. 1448-1631, with a median calibrated age of A.D. 1503. The calibrated radiocarbon date from the Susie Slade site, now the third date from the site on organic residue preserved on ceramic vessels, has a median calibrated age of A.D. 1771, and a 2 sigma age range of A.D. 1661-1815. The median calibrated dates for all three organic residue samples from the Susie Slade site range between A.D. 1769-1774, and the likeliest probabilities of the three calibrated dates overlap between A.D. 1720-1811, during the Historic Caddo period.

\section{ACKNOWLEDGMENTS}

Bo Nelson took the photographic image of the Susie Slade vessel used in this article. Patti Haskins of the Gregg County Historical Museum obtained the organic remains from the Susie Slade site for radiocarbon dating. We also appreciate the permission of the Texas Archeological Research Laboratory in obtaining deer bone samples from the Sanders site for radiocarbon dating purposes.

\section{REFERENCES CITED}

Jones, B. C.

1968 The Kinsloe Focus: A Study of Seven Historic Caddoan Sites in Northeast Texas. Master's thesis, Department of Anthropology, University of Oklahoma, Norman.

Krieger, A. D.

1946 Culture Complexes and Chronology in Northern Texas, with Extensions of Puebloan Datings to the Mississippi Valley. Publication No. 4640. The University of Texas, Austin.

Perttula, T. K.

2015 The Sanders Site (41LR2): A Middle to Historic Caddo Settlement and Mound Center on the Red River in Lamar County, Texas. Journal of Northeast Texas Archaeology 50, in press.

Perttula, T. K. and R. Z. Selden Jr.

2014 New Radiocarbon Dates from East Texas Caddo Sites. Journal of Northeast Texas Archaeology 47:1-8.

Perttula, T. K., R. Z. Selden Jr., and B. Nelson

2014 Documentation of Unassociated Ceramic Vessel Funerary Objects in the Gregg County Historical Museum Collections from Sites in Gregg, Harrison, and Panola Counties in East Texas. Special Publication No. 29. Friends of Northeast Texas Archaeology, Austin and Pittsburg.

Selden, R. Z. Jr. and T. K. Perttula

2013a Radiocarbon Trends and the East Texas Caddo Tradition (ca. A.D. 800-1680). Southeastern Archaeology 32(1):85-96.

2013b Temporal Dynamics of East Texas Caddo Sites with 10 or More Radiocarbon Dates. Journal of Northeast Texas Archaeology 41:81-99. 